\title{
Parasitoids Collected in Poultry Farms in Brazil
}

\author{
Carlos Henrique Marchiori
}

\section{ABSTRACT}

\begin{abstract}
The objective of this work is to report the presence of dipteran parasitoids in poultry farms in Brazil. The experiment was carried out in two poultry farms in the Midwest Region in Brazilian territory. The pupae were removed and individualized in glass capsules for the emergence of adult dipterans or parasitoids. The specie Pachycrepoideus vindemmiae (Rondani) (Hymenoptera: Pteromalidae) presented a frequency of $46.4 \%$ and showed parasitism of $93.9 \%$. The species Musca domestica (Diptera: Muscidae) presented a frequency of $93.3 \%$. Of the dipterans collected, the most important species was $M$. domestica for causing public health problems, disturbing people and being a vector of disease-causing agents.
\end{abstract}

Keywords: Arthropods; Insects; Dipterans; Himenopterans; Feces.
Published Online: June 02, 2021

ISSN: $2684-5199$

DOI: $10.24018 /$ ejbio.2021.2.3.203

\section{H. Marchiori*}

Instituto Federal Goiano, Goiânia, Goiás, Brazil.

(e-mail: chmarchiori@ ${ }^{@}$ yahoo.com.bror)

\section{INTRODUCTION}

Muscoid dipteran are widely distributed throughout the Neotropical region, and the ecological study, which is of great importance in controlling the spread of pathogens of various diseases to humans and animals [1].

In poultry farms, careful control of dipterans should be constant. It is important to remember that excessive fly production can cause, in addition to damage to poultry, disease transmission, low worker production due to continuous insect discomfort and decreased egg quality due to the presence of feces and bird regurgitation dipterans. Parasitoids, which include mainly taxa belonging to Hymenoptera Parasitic, play an important role in maintaining other populations of arthropods and mites, acting as regulators of host densities.

The purpose of this paper is to report the parasitoids of dipterans in poultry farms in Brazil.

\section{MATERIAL AND MethodS}

The experiment was carried out in two poultry farms in the Midwest Region in Brazilian territory (Fig. 1). Feces were removed from the farm sheds placed in 10 basins to be transported to the laboratory for removal of pupae. In the laboratory, pupae were obtained according to Marchiori [2]. The pupae were removed and placed on absorbent paper for drying and later individualized in glass capsules for the emergence of adult flies or parasitoids. The collections were carried out monthly from January to December 2007. Total percentage of parasitism was obtained by the number of parasitized pupae / total number of pupae collected x 100 .

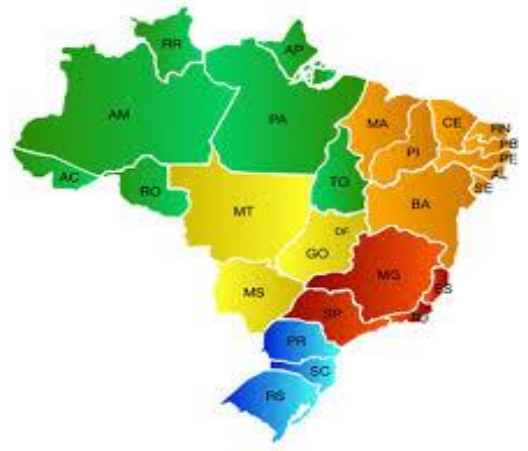

Fig. 1. Map of Brazil - Goiás (GO) region West Central Brazil (yellow color). Source: https://globalfranchise.com.br/auto-booking/glob-ft-mapa-brasil.

\section{RESULTS AND DISCUSSION}

From 10.608 pupae of dipteran collected 816 parasitoids emerged from 540 pupae (Table I).

The most collected species was Pachycrepoideus vindemmiae (Rondani) (Hymenoptera: Pteromalidae) (Fig. 2) with (379/816) 46.4\%. Parasitoid searching capacity, seasonality, and greater presence of its hosts in the collection area.

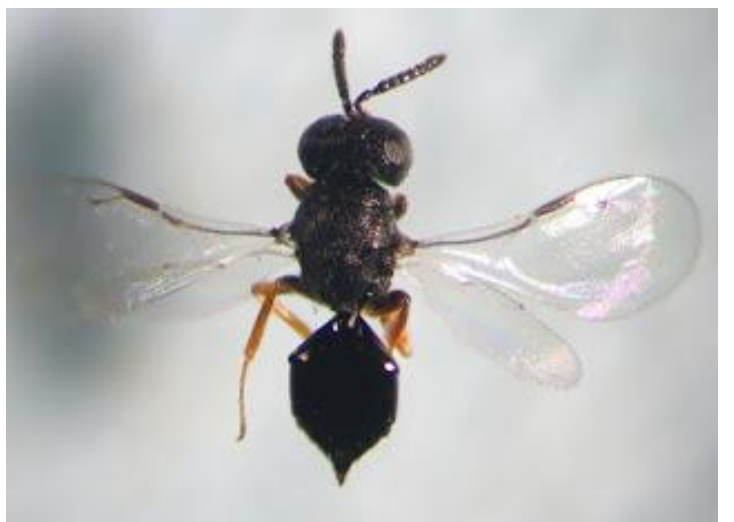

Fig. 2. Pachycrepoideus vindemmiae (Rondani) (Hymenoptera: Pteromalidae). Source: http://bestfreshglobal.blogspot.com/2016/08/pachycrepoideusvindemmiae-podria-ser.html. 
TABLE I: PARASITOIDES AND THEIR DiPTERANS Hosts COLleCted FROM POULTRY FARMS IN THE STATE OF GOIÁS, MidWEST REGION OF BRAZIL

\begin{tabular}{|c|c|c|c|c|c|}
\hline Diptera & $\begin{array}{l}\text { Number } \\
\text { of pupae }\end{array}$ & $\begin{array}{l}\text { Number of } \\
\text { specimens }\end{array}$ & $\begin{array}{c}\text { Pupae } \\
\text { parasitized }\end{array}$ & $\%$ & Specie of parasitoid \\
\hline \multicolumn{6}{|l|}{ Calliphoridae: } \\
\hline \multirow[t]{3}{*}{ Chrysomya megacephala } & 500 & 50 & 3 & 0.6 & Nasonia vitripennis \\
\hline & & 3 & 3 & 0.6 & Pachycrepoideus vindemmiae \\
\hline & & 3 & 3 & 0.6 & Spalangia endius \\
\hline \multicolumn{6}{|l|}{ Fanniidae: } \\
\hline \multirow[t]{2}{*}{ Fannia pusio } & 42 & 40 & 2 & 4.8 & Muscidifurax raptorellus \\
\hline & & 2 & 2 & 4.8 & Pachycrepoideus vindemmiae \\
\hline \multicolumn{6}{|l|}{ Muscidae: } \\
\hline \multirow[t]{9}{*}{ Musca domestica } & 9892 & 63 & 3 & 0.3 & Muscidifurax raptorellus \\
\hline & & 100 & 5 & 0.5 & Nasonia vitripennis \\
\hline & & 364 & 364 & 3.7 & Pachycrepoideus vindemmiae \\
\hline & & 12 & 12 & 0.1 & Spalangia cameroni \\
\hline & & 75 & 75 & 0.8 & Spalangia endius \\
\hline & & 17 & 17 & 0.2 & Spalangia nigra \\
\hline & & 8 & 8 & 0.1 & Spalangia nigroaenea \\
\hline & & 5 & 5 & 0.2 & Spalangia sp. \\
\hline & & 10 & 2 & 0.2 & Tachinaephagus zealandicus \\
\hline \multirow{5}{*}{$\begin{array}{c}\text { Sepsidae: } \\
\text { Palaeosepsis spp. }\end{array}$} & & & & & \\
\hline & 81 & 41 & 2 & 2.5 & Nasonia vitripennis \\
\hline & & 8 & 8 & $\begin{array}{c}10 . \\
0\end{array}$ & Pachycrepoideus vindemmiae \\
\hline & & 2 & 2 & 2.5 & Spalangia drosophilae \\
\hline & & 10 & 10 & 1.2 & Spalangia sp. \\
\hline \multirow{3}{*}{$\begin{array}{l}\text { Syrphidae: } \\
\text { Ornidia obesa }\end{array}$} & & & & & \\
\hline & 93 & 2 & 2 & 2.2 & Pachycrepoideus vindemmiae \\
\hline & & 2 & 2 & 2.2 & Spalangia cameroni \\
\hline Total & 10.608 & 816 & 540 & - & - \\
\hline
\end{tabular}

Pachycrepoideus vindemmiae generalist wasp that attacks pupae of several species cyclorrhaphous dipteran as a primary parasitoid. $P$. vindemmiae pupae remain concealed under the soil or manure until they are ready to emerge as adults [3].

Percentage of parasitism for each species of parasitoid was calculated according to the formula: number of parasitized puparium / by the number of host puparium $\mathrm{x}$ hundred.

The total percentage of parasitism found in this study was $5.1 \%(540 / 10.608)$ and species Muscidifurax raptorellus Kogan \& Legner (Hymenotera: Pteromalidae) with (5/504) 1.0\%, Nasonia vitripennis (Walker) (Hymenoptera: Pteromalidae) (10/504) 2.0\%, P. vindemmiae (367/504) 93.9\%, Spalangia cameroni Perkins (Hymenoptera: Pteromalidae) (12/504) 2.4\%, Spalangia drosophilae Ashmead (Hymenoptera: Pteromalidae) (2/504) $0.4 \%$, Spalangia endius Walker (Hymenoptera: Pteromalidae) (77/504) 15.2\%, Spalangia nigra Latrielle (Hymenoptera: Pteromalidae) (17/504) 3.3\%, Spalangia nigroaenea Curtis (Hymenoptera: Pteromalidae) (8/504) $1.6 \%$, Spalangia sp. (Hymenoptera: Pteromalidae) (15/504) $3.0 \%$ and Tachinaephagus zealandicus (Ashmead) (10/504) $2.0 \%$ (Encyrtidae).

The highest percentage of parasitism occurred with $P$. vindemmiae, probably due to its polyphagous habit. The $P$. vindemmiae species presented higher parasitism percentage in Palaeosepsis spp. (Diptera: Sepsidae), with $10.0 \%$ (Table I), probably due to the competitive ability of the young forms. This species also parasitized a greater diversity of dipterans species.

The species Musca domestica (Diptera: Muscidae) presented the highest frequency with $93.3 \%$. Of the dipterans collected, the most important species was $M$. domestica as it causes problems in public health, annoys people and is a vector of disease-causing agents and in poultry farming it causes economic damage in electrical installations [4].
Survey of these species of natural enemies, to assist in the adequate control of dipteran by means of integrated methods. The parasitoids are bioindicators of the degree of preservation of biomes [5].

\section{CONCLUSION}

The most collected species was $P$. vindemmiae $46.4 \%$ and the highest percentage of parasitism occurred with $10.0 \%$. Of the dipterans collected, the most important species was $M$. domestica.

\section{REFERENCES}

[1] J. A. Batista-da-Silva, G. E. Moya-Borja and M. M. C. Queiroz, "Ocorrência e Sazonalidade de Muscóides (Diptera, Calliphoridae) de Importância Sanitária no Município de Itaboraí, RJ, Brasil," EntomoBrasilis, vol. 3, no.1, pp. 16-21, 2010.

[2] C. H. Marchiori, "Microhimenópteros parasitoides de moscas em esterco bovino em Cachoeira Dourada, Goiás, Brasil," Entomologia y Vectores, vol. 9, pp. 365-374, 2002.

[3] P. E. Hanson and I. D. Gauld, The Hymenoptera of Costa Rica, 1st. ed. Oxford, U.K.: University Press Oxford, 1995.

[4] J. M. D'Almeida, "Calyptrate Diptera (Muscidae and Anthomyiidae) of the State of Rio de Janeiro - I. Synanthropy," Memórias do Instituto Oswaldo Cruz, vol. 87, pp. 381-386, 1992.

[5] D. Scatolini and A. M. Penteado-Dias, "A fauna de Braconidae (Hymenoptera) como bioindicadora do grau de preservação de duas localidades do Estado do Paraná," Revista Brasileira de Ecologia, vol. 1, pp. 84-8, 1997.

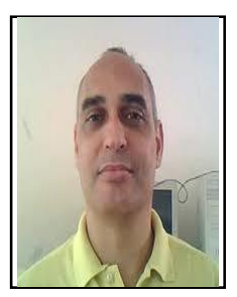

Dr. Carlos Henrique Marchiori is graduated in Biological Sciences from the Federal University of Uberlândia (1989), master's degree in Parasitology from the State University of Campinas (1993) and a $\mathrm{PhD}$ in Parasitology from the State University of Campinas (1997). He has experience in parasitology, with an emphasis in entomology and taxonomy of parasitoids, acting on the following topics: Diptera, Hymenoptera, parasitoids, biological control, and natural enemy. 